\title{
Kebutuhan perawatan periodontal remaja di Kabupaten Sinjai tahun 2007
}

\author{
Asdar Gani," Taufiqurrahman ${ }^{* *}$ \\ * Bagian Periodontologi \\ ** Mahasiswa Tingkat Profesi \\ Fakultas Kedokteran Gigi Universitas Hasanuddin Makassar
}

\begin{abstract}
This study was aimed to determine the periodontal treatment needs of teenagers in Kabupaten Sinjai. The study samples consisted of 306 subjects, age range between 15-20 years old, consisted 121 males and 185 females. Samples were selected through stratified random sampling from two different senior high schools in Sinjai. Flat dental mirror and CPITN probes were used in this study. Periodontal condition was evaluated using CPITN. The severity and prevalence of periodontal disease, as well as its frequency distribution were evaluated and reported according to gender, age, frequency of dental brushing, and sample's bad habit. In this study, only $11.8 \%$ of subjects demonstrated a healthy periodontal status. Bleeding was noted in $4.6 \%$ of subjects and calculus had the highest score (70.3\%). Shallow and deep pockets were found in $12.7 \%$ and $0.3 \%$ of the population studied, respectively. Hence, $11.8 \%$ of subjects didn't need periodontal treatment. Oral hygiene instruction, through demonstration, instruction, etc, was needed by $33.7 \%$ of subjects. Scaling and oral hygiene instruction was needed by $77.3 \%$. Then, $12.7 \%$ of subjects needed scaling and oral hygiene care. And $0.3 \%$ needed scaling, root planning and oral hygiene instruction. Scaling and oral hygiene instruction is the most needed periodontal treatment of teenagers in Sinjai.
\end{abstract}

Key words: CPITN, teenagers, periodontal treatment

\begin{abstract}
ABSTRAK
Penelitian ini bertujuan untuk mengetahui kebutuhan perawatan periodontal remaja di Kabupaten Sinjai. Sampel penelitian terdiri atas 306 remaja yang berusia 15-20 tahun, terdiri atas 121 laki-laki dan 185 perempuan. Sampel berasal dari 2 SMU di Sinjai, diperoleh dengan menggunakan metode stratified random sampling. Pemeriksaan menggunakan kaca mulut dan probe CPITN. Keparahan dan prevalensi penyakit periodontal serta distribusi frekuensinya dievaluasi dengan indeks CPITN dan dilaporkan berdasarkan jenis kelamin, umur, frekuensi menyikat gigi, dan kebiasaan buruk sampel. Dalam penelitian ini, terdapat $11,8 \%$ sampel yang memiliki jaringan periodontal yang sehat, $4,6 \%$ perdarahan dan tertinggi kalkulus $(70,3 \%)$. Poket dalam dan dangkal terdapat sebanyak $12,7 \%$ dan $0,3 \%$. Oleh karena itu, kebutuhan perawatan periodontal remaja di Sinjai adalah $11,8 \%$ tidak memerlukan perawatan, 4,6\% memerlukan peningkatan kebersihan mulut. Sebanyak $70,3 \%$ memerlukan skeling dan peningkatan kebersihan mulut, $12,7 \%$ memerlukan skeling dan perawatan kebersihan mulut, serta 0,3\% memerlukan peningkatan kebersihan mulut, skeling dan root planing. Skeling dan peningkatan kebersihan mulut merupakan jenis perawatan periodontal yang paling dibutuhkan oleh remaja di Kabupaten Sinjai.
\end{abstract}

Kata kunci : CPTIN, remaja, perawatan periodontal

Koresponden: Asdar Gani, Bagian Periodontologi, Fakultas Kedokteran Gigi Universitas Hasanuddin, Jl. Kandea No.5, Makassar, Indonesia. 


\section{Pendahuluan}

Penyakit periodontal adalah gangguan infeksi kronis yang disebabkan terutama oleh bakteri tertentu. Manifestasinya merupakan gambaran reaksi inang terhadap infeksi tersebut yang dimediasi oleh lingkungan sekitarnya. Ada dua bentuk penyakit periodontal yaitu gingivitis dan periodontitis. Gingivitis adalah reaksi jaringan gingiva terhadap akumulasi biofilm plak bakteri gigi. Sedangkan periodontitis bukanlah penyakit yang homogen, tetapi lebih sebagai sekumpulan penyakit yang saling berkaitan dengan manifestasi gambaran klinis sama tetapi mungkin berbeda penyebab dan proses biologisnya. Pada periodontitis, selain bakteri, juga harus ada faktor kepekaan inang. Faktor yang meregulasi kepekaan ini belum jelas, namun termasuk di dalamnya adalah respon imun dan respon lainnya terhadap bakteri periodontopatogen. ${ }^{1}$

Suatu penelitian oleh Albandar pada tahun 2002 menunjukkan data tingginya prevalensi gingivitis di Amerika, juga di belahan dunia lainnya di antara anak-anak, remaja, maupun dewasa. Selain itu ditemukan $82,1 \%$ mempunyai gingiva yang mudah berdarah. ${ }^{2}$

Kausa utama penyakit periodontal adalah iritasi bakteri yang terjadi karena adanya akumulasi plak. ${ }^{3}$ Plak adalah suatu massa bakteri yang tebal dan tidak mengalami kalsifikasi. Plak juga memiliki sifat yang dapat melekat erat pada permukaan gigi atau restorasi. Sumber utama mikroba plak adalah mikroorganisme mulut, komponen saliva, protein dan karbohidrat. Plak tetap melekat meskipun ada gerakan otot, aksi pembersihan saliva ataupun berkumur. ${ }^{4}$

Berdasarkan hubungannya dengan gingival margin, plak dibedakan menjadi dua kategori, yaitu plak supragingiva dan plak subgingiva. ${ }^{4}$

Apabila plak dibiarkan lebih lama, maka akan berubah menjadi kalkulus. Kalkulus merupakan plak yang mengalami kalsifikasi, yang terbentuk pada permukaan gigi alami atau gigitiruan. Kalkulus terbentuk dari plak bakteri yang mengalami mineralisasi. ${ }^{4}$

Walaupun akumulasi dan maturasi plak bakteri gigi menyebabkan perkembangan inflamasi jaringan gingiva terdekat, namun durasi, onset, dan intensitas proses inflamasi sangat bervariasi antar individu, bahkan antar gigi maupun sisi gigi dari orang yang sama. Prevalensi periodontitis agresif di Amerika pada remaja berusia 13-15 tahun dan 16-17 tahun, diketahui berturut-turut $0,4 \%$ dan $0,8 \%$. Sedangkan pada anak-anak dengan periodontitis kronis sebanyak $2,3-3,2 \%{ }^{2}$

Istilah remaja atau adolescence berasal dari kata latin adolescere yang berarti "tumbuh" atau "tumbuh menjadi dewasa". Istilah adolescence (bahasa Inggris) yang dipergunakan saat ini mempunyai arti yang cukup luas mencakup kematangan emosional, sosial dan fisik. Piaget mengatakan bahwa masa remaja adalah usia saat individu mulai berintegrasi dengan masyarakat dewasa. $^{5}$

Terdapat beberapa kebiasaan buruk yang sering dialami atau dilakukan oleh remaja yang dapat mempengaruh kesehatan jaringan periodontalnya, yaitu stres, merokok, konsumsi alkohol dan gangguan tidur dan nutrisi. ${ }^{1}$

Tujuan penulisan makalah ini adalah untuk memaparkan hasil penelitian mengenai Kebutuhan perawatan periodontal remaja di Kabupaten Sinjai pada tahun 2007.

\section{BAHAN DAN METODE}

Penelitian dilakukan pada murid sekolah menengah umum di dua kecamatan di Kabupaten Sinjai, yaitu Sekolah Menengah Umum Negeri (SMUN) I Kecamatan Sinjai Utara, dan SMUN I Kecamatan Sinjai Timur 
selama 3 hari, antara 14-16 Agustus 2007. Sampel berjumlah 305 orang dengan rincian 120 orang laki-laki dan 185 orang perempuan dengan rentang usia antara 15 sampai 19 tahun.

Untuk mengukur kedalaman poket digunakan probe periodontal yang mempunyai ujung berbentuk bola kecil dengan diameter $0,5 \mathrm{~mm}$. Area yang berwarna (sebagai skala) berada pada daerah 3,5-5,5 $\mathrm{mm}$.

Sampel diminta untuk mengisi kuisioner mengenai metode pembersihan mulut dan frekuensinya, serta beberapa jenis kebiasaan buruk yang sering dilakukan. Jaringan periodontal sampel dievaluasi dengan Indeks Kebutuhan Perawatan Periodontal Komunitas (CPITNCommunity Periodontal Index Treatment Needs). Pada indeks ini, rongga mulut dibagi dalam 6 sekstan. Sekstan 1 meliputi gigi 14, 15, 16, dan 17. Sekstan 2 meliputi gigi 11, 12, 13, 21, 22, dan 23. Sekstan 3 meliputi gigi 24, 25, 26, dan 27. Sekstan 4 meliputi gigi 34, 35, 36, dan 37. Sekstan 5 meliputi gigi 31, 32, 33, 41, 42, dan 43. Sekstan 6 meliputi gigi 44, 45, 46, dan 47.

Skor CPITN tertinggi di setiap sekstan setelah pemeriksaan dari empat sisi (labial, lingual/palatal, mesial, dan distal) dipakai sebagai nilai dari tiap sekstan. Skor 0 berarti kondisi jaringan periodontal sehat. Skor 1 berarti terjadi perdarahan ketika atau setelah dilakukan probing. Skor 2 berarti terdapat kalkulus supra atau subgingiva. Skor 3 berarti terdapat poket periodontal dengan kedalaman 4-5 mm, dan skor 4 berarti terdapat poket periodontal dengan kedalaman lebih dari 6 $\mathrm{mm}$.

Selanjutnya, ditentukan kategori kebutuhan perawatan berdasarkan skor tersebut di atas dari masing-masing sampel. Skor 0 artinya tidak membutuhkan perawatan. Skor 1 artinya membutuhkan peningkatan kebersihan mulut (melalui penyuluhan, demonstrasi, dan sebagainya). Skor 2 artinya memerlukan skeling dan peningkatan kebersihan mulut. Skor 3 artinya memerlukan skeling dan perawatan kebersihan mulut dan skor 4 artinya memerlukan memerlukan peningkatan kebersihan mulut, skeling dan root planing.

\section{HASIL PENELITIAN}

Tabel 1 menunjukkan bahwa distribusi sampel untuk skor CPITN berdasarkan umur, skor 0 terdistribusi terbesar pada umur 16 tahun, yaitu sebanyak 21 orang. Skor 1 juga terdistribusi terbesar pada pada usia 16 tahun, yaitu 7 orang. Sedangkan skor 2, terdistribusi terbesar pada usia 16 tahun dengan 100 orang, dan 15 tahun dengan 75 orang. Skor 3 dengan distribusi terbesar berada pada kelompok umur 16 tahun yaitu 20. Sementara skor 4 hanya terdapat pada kelompok umur 16 tahun yaitu sebanyak 1 orang atau $1 \%$.

Pada tabel di atas dapat terlihat perbedaan skor CPITN pada sampel laki-laki dan sampel perempuan. Untuk skor 0, skor 1, skor 2, skor 3, dan skor 4, semuanya ditemukan lebih banyak pada sampel perempuan. Jumlah yang terbanyak terjadi pada skor 2, yaitu menunjukkan perempuan 118 orang $(63,78 \%)$, sedangkan laki-laki 92 orang $(76,03 \%)$.

Dari kuisioner dan pemeriksaan terhadap metode serta frekuensi pembersihan rongga mulut sampel serta pengaruhnya terhadap kondisi jaringan periodontalnya serta kebiasaan-kebisaan buruk yang sering dialami/dilakukan sampel. Dari hasil kuisioner, diperoleh data bahwa 100\% sampel menggunakan sikat gigi untuk melakukan sikat gigi. 
Tabel 1. Distribusi sampel berdasarkan umur

\begin{tabular}{ccccccccc}
\hline \multirow{2}{*}{\begin{tabular}{c} 
Skor \\
\cline { 2 - 8 } CPITN
\end{tabular}} & \multicolumn{9}{c}{ Umur (tahun) } & \multicolumn{2}{c}{ Jenis kelamin } \\
\cline { 2 - 9 } & 15 & 16 & 17 & 18 & 19 & 20 & Laki-laki & Perempuan \\
\hline 0 & 12 & 21 & 8 & 0 & 0 & 0 & 10 & 31 \\
1 & 1 & 7 & 5 & 0 & 0 & 0 & 1 & 12 \\
2 & 75 & 100 & 29 & 5 & 0 & 1 & 92 & 118 \\
3 & 13 & 20 & 6 & 2 & 0 & 0 & 18 & 23 \\
4 & 0 & 1 & 0 & 0 & 0 & 0 & 0 & 1 \\
\hline
\end{tabular}

Tabel 2. Nilai skor CPITN terhadap kebiasaan buruk dan frekuensi menyikat gigi pasien

\begin{tabular}{cccccccccc}
\hline \multirow{2}{*}{$\begin{array}{c}\text { Skor } \\
\text { CPITN }\end{array}$} & \multicolumn{4}{c}{ Kebiasaan buruk } & \multicolumn{4}{c}{$\begin{array}{c}\text { Frekuensi sikat gigi } \\
\text { (kali/hari) }\end{array}$} \\
\cline { 2 - 11 } & Stres & Merokok & $\begin{array}{c}\text { Konsumsi } \\
\text { alkohol }\end{array}$ & $\begin{array}{c}\text { Gangguan } \\
\text { tidur }\end{array}$ & $\begin{array}{c}\text { Gangguan } \\
\text { pola makan }\end{array}$ & 1 & 2 & 3 & 4 \\
\hline 0 & 17 & 3 & 0 & 16 & 0 & 1 & 21 & 19 & 0 \\
1 & 4 & 0 & 0 & 7 & 2 & 0 & 8 & 5 & 0 \\
2 & 71 & 48 & 8 & 61 & 12 & 8 & 141 & 58 & 3 \\
3 & 15 & 8 & 1 & 16 & 0 & 3 & 24 & 14 & 0 \\
4 & 0 & 1 & 0 & 0 & 0 & 0 & 1 & 0 & 0 \\
\hline
\end{tabular}

Pada tabel Tabel 2, terlihat bahwa skor 2 CPITN paling banyak didapatkan pada sampel dengan fekuensi menyikat gigi dua kali sehari, yaitu 141 sampel. Kedua terbanyak adalah skor 2 yang menyikat gigi tiga kali sehari sebanyak 58 sampel.

Selain itu, tabel 2 juga memperlihatkan kondisi stres dengan skor 2 memiliki nilai tertinggi sebanyak 71 orang, merokok 48 orang, dan gangguan tidur 61 orang.

Dari hasil penelitian diperoleh bahwa status kebutuhan perawatan periodontal remaja di Kabupaten Sinjai adalah sebanyak 11,8\% tidak memerlukan perawatan periodontal. Sebanyak 4,6\% memerlukan peningkatan kebersihan mulut, antara lain melalui penyuluhan, demonstrasi. Sebanyak $70,3 \%$ memerlukan skeling dan peningkatan kebersihan mulut. Kemudian sebanyak $12,7 \%$ memerlukan skeling dan perawatan kebersihan mulut. Selebihnya, 0,3\%, memerlukan peningkatan kebersihan mulut, skeling dan root planing.

\section{PEMBAHASAN}

Penyakit periodontal terjadi sebagai akibat ketidakseimbangan antara mikroorganismemikrorganisme yang berpotensi patogen dalam poket periodontal dan mekanisme imun lokal atau sistemik inang. Buruknya kebersihan rongga mulut, merokok, stres, malnutrisi, dan terdapatnya penyakit sistemik merupakan faktor-faktor yang masih dapat dikendalikan. Selain itu juga terdapat faktor-faktor yang tidak terkontrol seperti usia, jenis kelamin, keturunan dan ras. Faktor-faktor tersebut tidak menyebabkan terjadinya penyakit periodontal secara langsung tapi dapat mempengaruhi kemungkinan seseorang terkena penyakit periodontal. $^{6}$

Pubertas merupakan suatu masa dalam perjalanan hidup, yaitu anak-anak akan menunjukkan pertumbuhan tanda-tanda kelamin sekunder (contohnya pada laki-laki, suara menjadi lebih berat dan pada wanita, tampak perkembangan payudara). Hal ini dipicu dengan adanya pituitary gland yang mensekresi sejumlah 
hormon ke dalam aliran darah dan memulai percepatan pematangan gonad, ovarium pada wanita dan testis pada pria. ${ }^{6}$ Ketika terjadi pubertas, terjadi peningkatan jumlah hormon. Hal ini dapat meningkatkan sensitivitas gingiva yang dapat mengakibatkan reaksi yang lebih besar terhadap berbagi iritan. Kondisi ini dapat mengakibatkan terjadinya gingivitis pubertas. ${ }^{8}$

Penelitian di negara-negara industri telah mencatat bahwa kesehatan gingiva perempuan lebih baik dibanding laki-laki. ${ }^{9}$ Di Israel, ditemukan kasus poket yang dalam pada pria 3 kali lebih banyak dibandingkan dengan wanita. ${ }^{10}$ Di Irak, pria sedikit lebih cenderung mengalami perdarahan dan poket yang dalam dibanding wanita, sementara prevalensi kalkulus dan poket yang dangkal lebih tinggi pada wanita. ${ }^{9}$ Sementara yang terjadi di Iran justru kebalikan dari apa yang ditemukan di Irak. Di Iran, wanita lebih banyak mengalami perdarahan dan poket dangkal, sementara kalkulus dan perdarahan lebih banyak pada laki-laki. ${ }^{11}$ Hal ini dikarenakan perempuan cenderung melaksanakan pembersihan mulutnya lebih baik dibanding laki-laki. ${ }^{9}$ Selain itu, faktor sosial dan perilaku anak laki-laki terarah pada masalah kebiasaan merokok, status sosial ekonomi, nutrisi, psikologis, dan konsumsi alkohol. $^{1}$

Para remaja menghadapi jenis stres yang spesifik. Ini bisa menjadi masalah di rumah dengan orang tua, orang tua yang alkoholik, dan orang tua yang bercerai atau tekanan dari guru di sekolah, tekanan dari teman-teman atau dari orang tua yang ingin semuanya berjalan baik. ${ }^{12}$ Stres dapat mengaktifkan sistem saraf pusat (SSP) dan sistem saraf otonom (SSO). Secara singkat, SSP yaitu korteks adrenal secara kronik akan melepas hormon kortisol yang jika berlebihan akan menekan imun sehingga meningkatkan pelepasan interleukin-1 dan 6 serta TNF. Sedangkan SSO secara akut menyebabkan medula adrenal melepaskan norepinefrin dan epinefrin sehingga prostaglandin dan protease diproduksi berlebihan. Kedua jalur ini menyebabkan terjadinya penyakit infeksi dan penyakit periodontal. ${ }^{1}$

Merokok merupakan aksi mekanisme dari salah satu faktor psikososial yang berdampak terhadap jaringan periodontal. Berbagai macam rokok dan intensitas kebiasaan merokok telah terbukti mempunyai hubungan kuat dengan status jaringan gingiva, kerusakan jaringan periodontal, serta keadaan periodontal. Hingga saat ini, belum ditemukan perbedaan yang jelas dari mikroflora periodontal dalam plak bakteri perokok dengan bukan perokok. Namun ditemukan kaitan merokok dengan perubahan sistem vaskularisasi dan imun inang gingiva. ${ }^{1}$

Salah satu cara cepat untuk lari dari masalah adalah penggunaan alkohol. Padahal cara ini justru akan menyebabkan terjadinya stres baru yang lebih kuat. Banyaknya konsumsi alkohol memberikan dampak berupa inflamasi gingiva, dan kerusakan jaringan periodontal. Beberapa keadaan biologis yang berubah akibat minum alkohol adalah kerusakan fungsi neutrofil dan defisiensi komplemen, gangguan mekanisme pembekuan darah karena kerusakan aktivitas protrombin dan vitamin $\mathrm{K}$, gangguan metabolisme tulang, dan gangguan penyembuhan. ${ }^{1}$

Jumlah jam tidur yang kurang dan makanan yang kurang bernutrisi akan mengganggu kesehatan umum yang secara tidak langsung mempengaruhi kesehatan jaringan periodontal. Hal lain yang sering dilakukan adalah malas untuk menyikat gigi dan tidak teratur sarapan karena merasa tidak ada waktu sehingga diganti dengan mengudap jajan. Nutrisi jajanan diketahui tidak seimbang atau tidak ideal. Jika asupan nutrisi bagi tubuh kurang, seperti kalsium, vitamin D, dan C sehingga daya tahan tubuh semakin menurun dan 
kehilangan gigi akibat kerusakan tulang alveolar makin meningkat. ${ }^{1}$

Pada penelitian ini diperoleh hasil bahwa skeling dan peningkatan kebersihan mulut merupakan jenis perawatan periodontal yang paling banyak dibutuhkan oleh remaja di Kabupaten Sinjai. Hasil yang sama juga ditemukan dari beberapa penelitian serupa yang telah dilakukan di berbagai belahan dunia. Sebuah penelitian di Minas Gerais Brazil menunjukkan $70 \%$ sampel remaja dari penelitian tersebut membutuhkan skeling dan peningkatan kebersihan mulut, ${ }^{13}$ seperti yang juga ditemukan di Enugu, Nigeria. ${ }^{14}$ Hasil yang sama, bahkan lebih tinggi, ditemukan dengan penelitian lain yang dilakukan di Sudan. Sebanyak 99,2\% sampel remaja pada penelitian tersebut membutuhkan skeling dan peningkatan kebersihan mulut. ${ }^{15}$ Begitu pula dengan yang terjadi di Iran, skeling dan peningkatan kebersihan mulut juga merupakan jenis perawatan periodontal yang paling dibutuhkan remaja di sana. ${ }^{11}$

Dari hasil penelitian ini dapat disimpulkan diperoleh bahwa kondisi periodontal remaja di Kabupaten Sinjai adalah sebanyak 11,8\% dalam kondisi normal, 4,6\% mengalami perdarahan, $70,3 \%$ terdapat kalkulus, $12,7 \%$ mengalami poket dangkal 4-6 mm, serta 0,3\% mengalami poket dalam yang lebih dari $6 \mathrm{~mm}$. Untuk itu, kebutuhan perawatan periodontal remaja di Kabupaten Sinjai adalah $11,8 \%$ tidak memerlukan perawatan, $4,6 \%$ memerlukan peningkatan kebersihan mulut antara lain melalui penyuluhan, demonstrasi, 70,3\% memerlukan skeling dan peningkatan kebersihan mulut, $12,7 \%$ memerlukan skeling dan perawatan kebersihan mulut, serta $0,3 \%$ memerlukan peningkatan kebersihan mulut, skeling dan root planing.

Berdasarkan simpulan di atas, disarankan agar dilakukan penelitian lanjutan, sehingga dapat diperoleh perbandingan data tentang kesehatan periodontal remaja di Kabupaten Sinjai dari waktu ke waktu.

\section{DAFTAR PUSTAKA}

1. Mustaqimah DN, Darmabrata W, Safrina H, Sukardi I. The effect of daily life style on periodontal health. Int J Dent 2005; 12(2): 67-9.

2. Albandar JM. Gobal risk factors and risk indicators for periodontal deseases. Periodontol 2000 2002; 29: 177-206.

3. Manson JD, Eley B.M. Buku ajar periodonti. Alih bahasa: Anastasia. $2^{\text {nd }}$ ed. Jakarta: EGC Penerbit Buku Kedokteran; 1993. p.44.

4. Newman MG, Takei HH, Carranza FA, editor. Carranza's clinical periodontology, $9^{\text {th }}$ ed. Philadelphia: Saunders; 2002. p. 96-7.

5. Rola F. Hubungan konsep diri dengan motivasi berprestasi pada remaja. USU Repository 2006; 15-6.

6. Wawrzyn-Sobczak K, Koslowska M, Stokowska W, Karczewski JK. The evaluation of paradontium of medical students of the medical university of Bialystok according to CPITN index. Roczniki Akademii Medycznej w Bialymstoku 2005; 50(1): 158

7. Adolescence. Available at http://en.wikipedia.org/wiki/Adolescence. Accessed: June 21st, 2007.

8. Fehrenbach MJ. Women's oral health needs. Prev Angle 2005; 4 (4): 2.

9. Khamrco TY. Assesment of periodontal disease using the CPITN index in a rural population in Ninevah, Iraq. Eastern Mediterranean Health J 1999; 5(3): 552.

10. Katz J, Peretz B, Sgan-Cohen HD, Horev T, Eldad A. Periodontal status by CPITN, and associated variables in an Israeli permanent force military population. J Clin Periodontol 2000; 27(5): 1.

11. Sanei A, Nikbakht-Nasrabadi A. Periodontal health status and treatment needs in Iranian adolescent population. Arc Iranian Med 2005; 8(4): 292.

12. Teen Stress. Available at http://library.thinkrequest/13561/english/teen stress.html. Accessed: June, $21^{\text {st }} 2007$. 
13. Pallos D, Sanches JC, Jose L, Cortelli R, Cortelli SC, de Souza DM, et al. Periodontal disease in a rural community in Minas Gerais, Brazil. Braz J Oral Scie 2005; 4(12): 661

14. Maduakor S, Lauverjat Y, Cadot S, Da Costa Noble R, Laporte $\mathrm{C}$, et al. Application of community periodontal index of treatment needs (CPITN) in Enugu (Nigeria): 31

15. Ali RW, Lie T. Periodontal conditions as measured by CPITN in Sudanese adolescent and adults in two cities in Sudan. Saudi Dent $\mathbf{J}$ 1994; 6(2): 85. 